\title{
Acid-soluble chromatin proteins from liver of genetically immobilized rabbit
}

\author{
J. PALYGA, E. GORNICKA, J. ZELNIK * and A. KOLATAJ \\ Department of Genetics, Educational University, 25-518 Kielce, Poland \\ * Research Institute of Animal Production at Nitra, Czechoslovakia
}

The acid-soluble chromatin proteins isolated from liver of normal and genetically immobilized rabbits were separated by one- and two-dimensional polyacrylamide gel electrophoresis. It was found that both histones and acid-soluble non-histones from normal and immobilized animals possesed similar banding patterns. Using two-dimensional gel electrophoresis were detected, however, minor quantitative differences among some nonhistone proteins.

In conclusion, our results demonstrated that the patterns of histones and acid-soluble nonhistone proteins from liver of normal and dyskinetic rabbit were strikingly similar. Subtele quantitative differences among nonhistone proteins may reflect metabolic differences between liver of normal rabbit and liver of rabbit with disorder of kinetic system.

\section{Acid-soluble nuclear proteins form liver of different chicken breeds. A comparative study by gel electrophoresis}

\author{
H. LUBON, H. SLIWINSKA, D. TYRAWSKA-SPYCHALOWA and A. KOLATAJ \\ Department of Biochem. Agric. TEACH. Univers., 8-110 Siedlce, \\ Dept. of Genetics Educat. Univers., 25-518 Kielce, Poland
}

Comparison by two-dimensional gel electrophoresis the acid-soluble nuclear proteins form the liver of chickens belonging to Leghorn, Zielononózka, Rhode Island Red, Polbar, Sussex, New Hampshire, Cornish and White Rock breeds showed that the proteins form various genotypic groups possessed similar electrophoretic patterns. All the prominent electrophoretic detectable histone, histone-like and nonhistone proteins fractions were present in livers of the chicken breeds examined. Most of these protein fractions were also present in similar relative amounts. However, each breeds exhibits a pattern which differs some quantitatively from others.

\section{Genetic and environmental trends for milk production in U.S. herds since 1960}

\author{
R.L. POWELL, H.D. NORMAN and F.N. DICKINSON \\ Animal Improvement Programs Laboratory, United States Department of Agriculture \\ Beltsville, Maryland 20705, U.S.A.
}

Trends in Holstein-Friesians in the United States were estimated from 4.8 million records of first-lactation cows calving from 1960 through 1980. Annual trends in breeding values of sires were $39 \mathrm{~kg}$ milk and $.95 \mathrm{~kg}$ fat over the 21 -year period. Trends in sire breeding values were only $5 \mathrm{~kg}$ milk and $.06 \mathrm{~kg}$ fat during the 1960 's compared with $87 \mathrm{~kg}$ milk and $2.55 \mathrm{~kg}$ fat from 1978 through 1980. Cow breeding values estimated as a function of sire breeding values in various generations increased by $62 \mathrm{~kg}$ milk and $1.71 \mathrm{~kg}$ fat per year for the last 3 years. 